\title{
ICHTHYOFAUNA OF THE LOWER COURSE OF THE PRUT RIVER (LARGA RIVER SECTOR (KM 120) - CONFLUENCE WITH RIVER DANUBE)
}

\author{
Ana Dadu ${ }^{1}$, Neculai Patriche ${ }^{2}$, Denis Bulat ${ }^{1}$, Floricel Maricel Dima ${ }^{2}$, \\ Nicolae Șaptefrați ${ }^{1}$, Magdalena Tenciu ${ }^{2}$ \\ ${ }^{1}$ Institute of Zoology, Chisinau, Moldova, e-mail: anita_dadu@mail.ru \\ ${ }^{2}$ Research and Development Institute for Aquatic Ecology, Fisheries and Aquaculture, Galati \\ Romania
}

\section{Summary}

The present written work represents the results of the research of the ichthyofauna from the lower course of the Prut River (including the Manta puddle and the Beleu lake) in terms of succession. It was established that, as a result of anthropogenic actions (drying of over 27-30 thousand ha of puddles, dam of the banks of the Prut River and its tributaries, extraction of sand and river stone from the minor riverbed, irreversible use of water in irrigation and industries, pollution, construction of the Costești-Stânca dam, destruction of wood cuts for lithifile and phytophilic species, etc.) in the ichthyofauna on the lower course of the Prut River, there were significant changes in diversity, quantitative and qualitative composition, and functional status of fish populations.

\section{Introduction}

The Prut River on the km section 120 (mouth of the river Larga (left tributary) to the confluence with the Danube River is characterized by a slow flow regime (instability during floods and showers) with major floodplain.

The flow and water level depends on the amount of atmospheric deposits that vary according to the type and seasonal changes, being unevenly distributed throughout the basin - the water level withstands large fluctuations. The lowest atmospheric deposits occur in winter and the highest in summer in the form of showers. Melting snow and spring rains as well as summer showers condition the spring and summer floods. Spring floods usually begin in late February - early March, approximately with the thawing of ice.

Raising the water level during this period, on average, is $0.3-0.6 \mathrm{~m}$ reaching up to $1 \mathrm{~m}$ over 24 hours. During the summer floods (most intensive in July - August) the rise of the level also occurs quite abruptly. In the last 3 years, the spring-summer floods have shifted in May-July.

On this section, the river has many meanders, and the banks have low slopes - floodplain. Both banks are covered with tree roots, shrubs and macrophytes on which favorable conditions are created for the natural reproduction of the main fish species. For fattening, mainly Manta puddle and Beleu lake are used.

\section{Methods and materials applied}

During the years 2020 - 2021, the ichthyological material was collected by carrying out control fishing with nets and stationary and drifting with the size of the eye on the side 32-4045-50-55-70-100 mm, with a length of $25 \mathrm{~m}$ and $50 \mathrm{~m}$, the net for brood L - 5 - 20-50m, h - 1,5 - 2m, Ø 10x10 - 20x20 mm, ichthyoplankton mesh and fishing net race. The determination and 
analysis of the ichthyological material was performed using classical ecological and ichthyological methods $[8,9,10,17,19,20,21]$. The data obtained were statistically processed using the program Excel - 2007. In total, 2183 fish were collected in the years 2020 - 2021.

Also, for the synthesis analysis of the results of multiannual scientific research of the Laboratory of Ichthyology and Aquaculture of the Institute of Zoology on the state of fish fauna in the Prut River (lower course) from the mouth of the river Larga (km 120) to the confluence with the Danube.

In the quantitative and qualitative description of the ichthyofauna on this segment of the Prut River were also used the results of the scientific research carried out by the Research Station in the Field of Fish Culture, the Department of Zoology of the Pedological Institute from Tiraspol, Research-Development Institute for Aquatic Ecology, Fisheries and Aquaculture Galati, as well as ichthyologic observations made by the State Inspectorate for the Protection and Reproduction of Fishery Resources and Fisheries Regulation in the Republic of Moldova.

\section{Results obtained and discussions}

Scientific research carried out (since the 50th century and until now) on the fish fauna of the lower course of the Prut River has found that until the regularization of the flow of the Prut River (Costești - Stânca dam, 1978) the ichthyofauna of the Prut River basin, after some authors, it consisted of 98 species and subspecies of fish, assigned to 23 families [3, 4, 6, 18]. After the regularization of the flow as well as the development of massive amelioration measures (drying of the puddles in the lower course - about 27-30 thousand ha and damming of the banks) essential changes have taken place in the specific diversity of the ichthyofauna. Valuable species have disappeared such as: - starlet, basratd strungeon, burbot, eel.

The population of some semi-migratory species and potamodromes have significantly decreased (ide, carp, vimba bream, sichel). Simultaneously with the introduction of valuable fish species, from the Amur River, new species have completed the ichthyofauna - silver carp, bighead, mackerel, etc. Therefore, at the end of the 70s (last century) the fish fauna of the lower course of the Prut River consisted of 54 species and subspecies of fish assigned to 19 families (aa. 1960-1974 - 16 families, a. 2017 -15 families).

The next period (from the mid-1980s to the present) is characterized by intensified negative anthropogenic influence, regularization of tributary flows, pollution, damming of many parts of banks against floods, excavation and extraction of sand, gravel and river stone, irreversible use of water for irrigation, industries and other activities related to the aquatic ecosystems.

These productive activities have caused substantial changes in the specific diversity of fish fauna and have led to a change in the ecological status of many fish species as well as to the degradation of the populations of economically valuable and endangered species.

From the composition of the ichthyofauna, burbot, Danube streber, barbel, huchen, crucian crap have practically disappeared. The population of starlet, ide, eastern mudminnow, etc. is on the verge of extinction. They passed in the category of rare species - mackerel of Danube, sichel, tench, barbel, spined loach $[3,4]$. The populations of economically valuable species 
(previously numerous) have been considerably reduced - asp, pike-perch, carp, catfish, freshwater bream, vimba bream, pike. On the other hand, some species have adapted to the new environmental conditions, expanded their range, and their populations are progressing. The mentioned ones refer first to the species without economic value (Stone moroko, gudgeon, bleak, rudd, european perch, silver crucian carp (forms with low growth rate).

In connection with the border regime, industrial / commercial fishing in the Prut River was not practiced, this being the reason why no obvious statistics were taken. Industrial / commercial fishing was practiced only in the puddles located downstream of Tुiganca. In the period immediately after the Second World War, starting with 1946, industrial / commercial fishing was organized and, annually, until 1967, 495 tons were fished.

Until 1959, carp predominated in catches - 150 tons (30\% of catches), followed by pike 90 tons (18\% of catches), catfish - 16 tons and freshwater bream- 7 tons [7].

The drying of over 27000 ha of ponds during the years 1950 - 1960, essentially modified the aquatic ecosystems in this area, and from the famous puddles only the puddles from the village of Manta (2200 ha) and Lake Beleu from the area of Slobozia Mare (900 ha) remained.

With the drying of the ponds, important areas for the reproduction of many valuable species, the development of juveniles fish, the growth and fattening of fishing species (carp, freshwater bream, pike-perch, pike, tench, catfish, etc.) were liquidated.

Catches of industrial / commercial fishing, during the years 1968-1970, decreased to 227 tons, and towards the end of the 70 s of the last century up to 100 tons dominant in catches becoming the silver crucian carp - 28 tons and bream -20 tons [7 ] (Tab. 1).

Tab. 1 The dynamics of industrial fishing in Manta puddle and Lake Beleu in the Prut River basin (tons).

\begin{tabular}{|c|c|c|c|c|c|c|c|c|c|c|c|c|}
\hline Years & Carp & $\begin{array}{c}\text { Freshwa- } \\
\text { ter } \\
\text { Bream }\end{array}$ & $\begin{array}{c}\text { Pi- } \\
\text { ke-Per- } \\
\text { ch }\end{array}$ & Asp & Catfish & $\begin{array}{c}\text { Crucian } \\
\text { Carp }\end{array}$ & Pike & Tench & Rudd & $\begin{array}{l}\text { Euro- } \\
\text { pean } \\
\text { Perch }\end{array}$ & $\begin{array}{c}\text { Other } \\
\text { species } \\
*\end{array}$ & Total \\
\hline 1 & 2 & 3 & 4 & 5 & 6 & 7 & 8 & 9 & 10 & 11 & 12 & 13 \\
\hline 1946 & 178,4 & 24,1 & 32,4 & 0 & 41,0 & 0 & 27,0 & 0 & 35,0 & 16,0 & 141,9 & 495,8 \\
\hline 1947 & 21,9 & 4,8 & 1,1 & - & 6,1 & - & 13,7 & - & - & - & 84,7 & 132,3 \\
\hline 1948 & 211,4 & 5,1 & 5,7 & - & 2,4 & - & 2,4 & - & - & - & 530,0 & 757,0 \\
\hline 1949 & 349,7 & 23,8 & 4,6 & - & 19,7 & - & 107,9 & - & - & - & 352,1 & 857,8 \\
\hline 1950 & 374,2 & 27,6 & 1,7 & 6,0 & 11,6 & - & 89,4 & - & - & - & 266,8 & 777,3 \\
\hline 1951 & 102,3 & 14,7 & - & 1,2 & 6,1 & - & 43,1 & - & - & - & 237,4 & 404,8 \\
\hline 1952 & 96,1 & 10,1 & 0,1 & 1,2 & 5,3 & 6,4 & 60,0 & 3,6 & 21,3 & 10,7 & 206,2 & 421,0 \\
\hline 1953 & 120,6 & 12,8 & 0,4 & - & 6,6 & 2,8 & 43,9 & 2,0 & 23,8 & 18,5 & 176,1 & 407,5 \\
\hline 1954 & 74,0 & 11,9 & - & - & 4,2 & 8,3 & 41,6 & 5,9 & 8,5 & 2,3 & 126,4 & 283,1 \\
\hline 1955 & 112,1 & 6,5 & - & 0,2 & 20,6 & - & 98,7 & 5,6 & 5,0 & 13,0 & 143,6 & 405,3 \\
\hline 1956 & 128,6 & 22,5 & 0,7 & 1,0 & 36,9 & 32,8 & 355,0 & 38,3 & 51,4 & 48,6 & 207,5 & 923,3 \\
\hline 1957 & 159,0 & 5,6 & 0,3 & 0,5 & 28,0 & 8,7 & 162,4 & 13,6 & 10,3 & 9,6 & 236,0 & 634,0 \\
\hline 1958 & 77,0 & 4,9 & - & - & 18,2 & 10,0 & 94,4 & 25,0 & 17,2 & 7,0 & 191,4 & 445,1 \\
\hline 1959 & 80,0 & 3,6 & - & - & 18,8 & 9,2 & 103,9 & 20,0 & 15,0 & 5,0 & 187,8 & 443,3 \\
\hline
\end{tabular}




\begin{tabular}{|c|c|c|c|c|c|c|c|c|c|c|c|c|}
\hline 1960 & 22,7 & 0,4 & - & - & 16,8 & - & 101,2 & 20,0 & 16,0 & 5,0 & 227,5 & 409,6 \\
\hline 1961 & 12,4 & 1,4 & - & 0,5 & 10,7 & 8,4 & 67,7 & 40,2 & - & 13,4 & 232,0 & 386,7 \\
\hline 1962 & 17,3 & 2,1 & - & - & 3,1 & 106,0 & 63,6 & 23,7 & 19,9 & 34,4 & 126,8 & 396,9 \\
\hline 1963 & 11,0 & 1,7 & - & - & 7,1 & 91,5 & 117,8 & - & 31,6 & 46,2 & 171,5 & 478,4 \\
\hline 1964 & 13,9 & 1,6 & - & - & 3,9 & 45,6 & 44,7 & - & 9,1 & 23,3 & 102,4 & 244,5 \\
\hline 1965 & 4,8 & 4,5 & - & 0,9 & 16,0 & 1,0 & 71,9 & - & 15,6 & 29,9 & 188,2 & 332,8 \\
\hline 1966 & 6,4 & 31,4 & 1,5 & 0,3 & 39,5 & 43,8 & 68,5 & - & 10,8 & 25,0 & 187,6 & 414,8 \\
\hline 1967 & 15,4 & 9,0 & 0,7 & 0,2 & 18,2 & 78,4 & 51,3 & 0,4 & 10,0 & 27,9 & 199,5 & 411,0 \\
\hline 1968 & 1,4 & 4,4 & 0,2 & - & 8,2 & 3,7 & 35,6 & 0,1 & 11,0 & 4,8 & 157,7 & 227,1 \\
\hline 1969 & 2,0 & 4,8 & - & - & 11,0 & 34,5 & 43,6 & 6,7 & 82,7 & 19,0 & 67,7 & 272,0 \\
\hline 1970 & 6,1 & 3,6 & 0,1 & - & 8,1 & 4,4 & 44,8 & 11,2 & 43,7 & 4,4 & 96,8 & 223,2 \\
\hline 1971 & 4,0 & 3,5 & 1,4 & - & 6,2 & 18,4 & 22,4 & 5,4 & 33,3 & 13,2 & 45,9 & 153,7 \\
\hline 1972 & 5,1 & 3,8 & 3,2 & - & 12,0 & 22,6 & 13,7 & 1,2 & 20,4 & 5,2 & 90,6 & 177,8 \\
\hline 1973 & 5,0 & 14,0 & 6,0 & - & - & 13,0 & 8,0 & - & 18,0 & 6,0 & 42,0 & 112,0 \\
\hline 1974 & 3,0 & 17,7 & 4,4 & - & 19,1 & 52,4 & 12,9 & - & - & - & 58,7 & 168,2 \\
\hline 1975 & 18,8 & 34,7 & 9,3 & - & 14,6 & 43,7 & 6,8 & - & 10,1 & 15,1 & 35,1 & 188,2 \\
\hline 1976 & 38,0 & 11,9 & 22,5 & - & 3,3 & 24,2 & 3,7 & - & 24,2 & 14,0 & 13,2 & 155,0 \\
\hline 1977 & 20,6 & 2,4 & 3,4 & - & 9,4 & 9,5 & - & - & 30,2 & 30,0 & 19,1 & 124,6 \\
\hline 1978 & 25,4 & 5,3 & 1,9 & - & 11,6 & 45,3 & - & - & - & - & 22,8 & 112,3 \\
\hline 1979 & 24,0 & 17,9 & 2,8 & - & 7,0 & 41,1 & 1,8 & - & 17,0 & 21,0 & 7,4 & 140,0 \\
\hline 1980 & 13,6 & 17,3 & 5,7 & 3,2 & 9,0 & 35,9 & 3,2 & - & 5,9 & 6,0 & 2,2 & 102,0 \\
\hline 1981 & 7,8 & 30,1 & 6,8 & 1,4 & 5,6 & 30,8 & 2,2 & - & 1,5 & 11,0 & 13,0 & 110,2 \\
\hline 1982 & 12,4 & 29,9 & 7,0 & 0,6 & 3,3 & 39,9 & - & - & 1,5 & - & 5,0 & 99,6 \\
\hline 1983 & 12,5 & 48,6 & 6,9 & - & 2,5 & 24,8 & - & - & - & - & 3,6 & 98,9 \\
\hline 1984 & 9,4 & 48,8 & 7,7 & - & 4,8 & 29,2 & - & - & - & - & 8,4 & 108,3 \\
\hline 1985 & 32,0 & 28,8 & 2,1 & 1,7 & 1,9 & 38,4 & 1,0 & - & 2,0 & 2,2 & 9,4 & 119,5 \\
\hline 1986 & 5,0 & 11,0 & 1,2 & 1,3 & - & 19,0 & 0,8 & - & - & 3,7 & 3,1 & 45,1 \\
\hline 1987 & 12,8 & 5,3 & 0,1 & 1,3 & 0,2 & 10,6 & 1,0 & - & - & - & 5,0 & 36,3 \\
\hline 1988 & 26,7 & 10,9 & 4,6 & - & 3,1 & 11,3 & - & - & - & - & 22,1 & 78,7 \\
\hline 1989 & 29,2 & 12,8 & 1,3 & - & 2,2 & 14,4 & - & - & - & - & 24,9 & 84,8 \\
\hline 1990 & 10,3 & 8,6 & 0,5 & - & 0,1 & 5,0 & - & - & - & - & 7,6 & 32,1 \\
\hline 1991 ** & - & - & - & - & - & - & - & - & - & - & - & - \\
\hline 1992 & 2,2 & 4,8 & - & - & - & 5,0 & - & - & - & - & 12,2 & 24,2 \\
\hline 1993 & 0,7 & 1,2 & 1,0 & - & - & 10,1 & - & - & - & - & 17,0 & 30,0 \\
\hline 1994 & - & 0,8 & - & - & - & 0,2 & - & - & - & - & 2,4 & 3,4 \\
\hline 1995 & - & - & - & - & - & 1,1 & - & - & - & - & 1,7 & 2,8 \\
\hline 1996 & 0,2 & 1,1 & - & - & - & - & - & - & - & - & - & 1,3 \\
\hline 1997 & - & - & - & - & - & - & - & - & - & - & - & - \\
\hline 1998 & - & - & - & - & - & - & - & - & - & - & - & - \\
\hline 1999 & - & - & - & - & - & - & - & - & - & - & - & - \\
\hline 2000 & - & - & - & - & - & - & - & - & - & - & 0,6 & 0,6 \\
\hline
\end{tabular}




\begin{tabular}{|c|c|c|c|c|c|c|c|c|c|c|c|c|}
\hline $\mathbf{2 0 0 1}$ & - & - & - & - & - & - & - & - & - & - & 0,2 & 0,2 \\
\hline $\mathbf{2 0 0 2}$ & - & - & - & - & - & 0,14 & - & - & - & - & 0,05 & 0,19 \\
\hline $\mathbf{2 0 0 3}$ & 0,26 & 0,15 & 0,1 & - & - & 1,0 & - & - & 0,11 & 0,1 & 0,18 & 1,9 \\
\hline $\mathbf{2 0 0 4}$ & - & - & - & - & - & - & - & - & - & - & - & - \\
\hline $\mathbf{2 0 0 5}$ & 0,4 & 0,2 & 0,2 & - & - & 0,4 & 0,2 & - & - & - & - & 1,4 \\
\hline
\end{tabular}

* Other species included: white bream, white-eye-bream, roach, ruffe, common nase, fitofagus, round goby, bleak, sichel .

**In connection with the inclusion of Lake Beleu in the component of the nature reserve "Prutul de Jos", since 1991, industrial fishing took place only in the Manta puddles where, since 2006, it is no longer practiced.

Control and scientific fisheries conducted during the years 1981-1991 as well as the analysis of catches from industrial / commercial fishing found that ichthyofauna was represented by 36 species of which 12 species from the fishing group, but only 9 species of all were of economic importance: roach, asp, freshwater bream, vimba bream, white-eye-bream, silver crucian carp, carp, catfish, pike-perch[11, 22] (Tab. 2, 3).

In the catches, the following species were completely missing: starlet, ide, barbel, sichel, white bream etc., which in previous years were found very common. Of the rare species, in June 1991, one eel (length $1.05 \mathrm{~m}$, weight $1.2 \mathrm{~kg}$ ) was caught in the Manta puddles and another eel of $58 \mathrm{~cm}$ in length was fished in May 2003, as well as starlet (from fishermen's reports have not been reported in this area since 1984).

Tab. 2 The qualitative and quantitative composition of the fish fauna from the Prut river in the area of Văleni village a. 1981

\begin{tabular}{|c|c|c|c|c|c|c|c|c|c|}
\hline \multirow{3}{*}{ Fish species } & \multirow{3}{*}{$\begin{array}{c}\text { No. } \\
\text { of fish } \\
\text { examined }\end{array}$} & \multirow{3}{*}{$\begin{array}{c}\begin{array}{c}\text { Species } \\
\text { ratio \% }\end{array} \\
\text { abundance }\end{array}$} & & \multicolumn{3}{|c|}{ Body length, $\mathrm{cm}$} & \multicolumn{3}{|c|}{ Ichthyomas, $g$} \\
\hline & & & \multicolumn{3}{|c|}{ Values } & \multicolumn{3}{|c|}{ Values } & \multirow[b]{2}{*}{$\max$} \\
\hline & & & Ichthyomas & average & $\min$ & $\max$ & average & $\min$ & \\
\hline $\begin{array}{c}\text { Freshwater } \\
\text { bream }\end{array}$ & 38 & 33,33 & 14,0 & 19,5 & 12,0 & 35,0 & 205 & 45 & 650 \\
\hline $\begin{array}{c}\text { European } \\
\text { Perch }\end{array}$ & 16 & 14,07 & 6,0 & 17,5 & 16,0 & 24,3 & 200 & 70 & 330 \\
\hline Asp & 15 & 13,15 & 30,3 & 40,6 & 30,3 & 62,0 & 1220 & 500 & 3270 \\
\hline Pike & 11 & 9,64 & 7,8 & 31,7 & 26,8 & 40,0 & 409 & 170 & 725 \\
\hline Pike-perch & 10 & 8,77 & 8,3 & 32,1 & 27,9 & 34,8 & 471 & 290 & 595 \\
\hline Catfish & 9 & 8,89 & 12,3 & 41,9 & 29,8 & 78,5 & 795 & 250 & 3470 \\
\hline Carp & 6 & 5,26 & 11,0 & 36,0 & 24,0 & 51,0 & 450 & 300 & 600 \\
\hline $\begin{array}{l}\text { Silver cru- } \\
\text { cian carp }\end{array}$ & 7 & 6,14 & 4,6 & 2,5 & 21,3 & 28,0 & 368 & 325 & 440 \\
\hline Barbel & 2 & 1,75 & 5,5 & 50,0 & 46 & 54,0 & 1510 & 1120 & 1900 \\
\hline In total & 114 & & & & & & & & \\
\hline
\end{tabular}


Tab. 3 The qualitative and quantitative composition of the fish fauna from the Prut river on the segment of Brînza village - Câșlița village in the aa period. 1990-1991

\begin{tabular}{|c|c|c|c|c|c|c|c|c|c|}
\hline \multirow{3}{*}{ Fish species } & \multirow{3}{*}{$\begin{array}{c}\text { No. } \\
\text { of fish } \\
\text { examined }\end{array}$} & \multirow{3}{*}{$\begin{array}{l}\begin{array}{l}\text { Species } \\
\text { ratio \% }\end{array} \\
\text { abundance }\end{array}$} & & \multicolumn{3}{|c|}{ Body length, $\mathrm{cm}$} & \multicolumn{3}{|c|}{ Ichthyomas, $g$} \\
\hline & & & \multicolumn{3}{|c|}{ Values } & \multicolumn{3}{|c|}{ Values } & \multirow[b]{2}{*}{$\max$} \\
\hline & & & Ichthyomas & average & $\operatorname{mini}$ & $\max$ & average & $\min$ & \\
\hline Eel & 1 & - & - & - & - & - & - & - & - \\
\hline Roach & 78 & 12,5 & 5,2 & 15,7 & 13,7 & 18,8 & 165,6 & 120 & 190,5 \\
\hline Asp & 54 & 8,6 & 5,7 & 31,7 & 22,2 & 58,1 & 260,1 & 205 & 305,5 \\
\hline $\begin{array}{l}\text { Freshwater } \\
\text { bream }\end{array}$ & 85 & 13,5 & 8,8 & 31,0 & 16,4 & 35,5 & 256,8 & 205 & 305,5 \\
\hline $\begin{array}{l}\text { White-eye- } \\
\text { bream }\end{array}$ & 66 & 10,6 & 3,0 & 16,6 & 15,2 & 24,2 & 12,7 & 100 & 210,0 \\
\hline Vimba bream & 4 & 0,6 & 1,4 & 16,2 & 10,5 & 24,2 & 103,2 & 34 & 150 \\
\hline $\begin{array}{l}\text { Silver cru- } \\
\text { cian carp }\end{array}$ & 202 & 32,5 & 25,2 & 14,1 & 8,2 & 25,8 & 197,4 & 20 & 365 \\
\hline Carp & 100 & 16,0 & 43,2 & 33,6 & 8,4 & 41,3 & 1060,1 & 850 & 2332,0 \\
\hline Catfish & 18 & 2,9 & 3,9 & 36,9 & 25,2 & 62,5 & 525,0 & 275 & 3350,0 \\
\hline Pike-perch & 17 & 2,8 & 3,5 & 33,4 & 25,5 & 40,2 & 499,3 & 280 & 7905 \\
\hline In total & 624 & 100 & & & & & & & \\
\hline
\end{tabular}

Annually, in the pre-reproductive period, there are massive migrations of carp, freshwater bream, roach, crucian carp, asp, catfish and other species from the Danube River to the breeding sites. From May to the beginning of July, the juveniles and the young fish are taken by the current of the river water downstream to fl. Danube. In years 1990-1991 according to the numerical abundance, roach, freswater bream, crucian carp and carp predominated and after ichthyomas (specific weight): carp, catfish, crucian carp, freshwater bream, asp. The significant decrease in ichthyofauna was due to low water levels, intensive pollution, lack of natural floods and showers, low water levels in the Danube River, which disturbed the natural reproduction, development and growth of fish in various ontogenetic stages.

Another negative factor that contributed to the reduction of fishery resources on the lower course of the Prut, Manta puddles and in Lake Beleu was the regularization of water flows by building the Costeşti-Stânca dam (1979), changing the hydrological regime of the river.

The current state of the fishery resources in the Prut puddles entirely depends on the degree of water supply and the penetration of fish from the Danube-Prut river system. As a result of systematic ichthyological research and observations, it was found that the intensive entry of fish for reproduction and fattening in the Manta puddle and Beleu lake occurred during the periods with the average annual flow of the Prut River of $80 \mathrm{~m} 3 / \mathrm{s}$ and the increase of water level in river Danube.

With the regularization of the Prut flow, the average annual water flow is $50 \mathrm{~m} 3 / \mathrm{s}$ with variations from $31 \mathrm{~m} 3 / \mathrm{s}$ to $77 \mathrm{~m} 3$ / s. In such conditions, fish no longer enter the Prut puddles, 
and industrial fishing, from the years 90 (last century), are no longer practiced and have lost their importance for reproduction where the areas of cattle breeders were about 750-900 ha in Manta puddle and 300-500 ha in Lake Beleu [16].

A negative impact on the aquatic biological resources in the Prut River basin was also caused by various economic activities: extraction of sand, gravel and river stone (only the Republic of Moldova, since the sixth decade, last century, annually excavated from the minor riverbed 360 - 380 thousand $\mathrm{m} 3$ of sand and gravel); irreversible use of water for various purposes (on the left bank there were 35 pumping stations - most were operated without fish protection facilities); wastewater pollution; irrational exploitation of fishery resources (lack of a common agreement with Romania on joint research on the state of fishery resources, regulation and record of fishing, improvement of fisheries measures, prevention of illegal fishing) [7].

Significant changes in the water level and flow regime occurred, especially in the lower course after the regularization of the Prut River flows and the commissioning of the Costești-Stânca reservoir. Over the years, with more water, during the period of increasing level, to a greater or lesser extent, the puddles and lakes in the Prut meadow are connected to the riverbed by ravines and canals which are often barred (clogged) and cannot ensure the normal water supply of lakes with average depths of 1-2m. In some years, for example in 1990, Lake Beleu has dried up completely and the entire surface was covered with macro-vegetation, losing its fishing importance. During the great floods of spring and summer and the flooding of the lakes, as it was in 1991, due to the abundant atmospheric deposits, favorable conditions were created for the reproduction of the fish and the fattening of the juveniles fish. Downstream of the town. Leova riverbed, until 1967, was bordered by lakes and puddles. After their drying (approximately 27000 - 30000 ha) only the Manta puddle (2100 ha) and the Beleu lake (900 ha) were preserved, which are fed with water, predominantly from the Prut River, and a large part of the lake surfaces they are covered with macrophytes constituting the main places for the natural reproduction of many species of fish, the development and fattening of the juveniles fish.

The influence of water flow on the effectiveness of natural reproduction is demonstrated by the years 1989-1990, that are completely different due to the water flow in the spring-summer period. In 1990, only 10 species of fish were identified compared to 1989 (19 species), and the share of species with economic value decreased 3 times from 8.7 million. (a. 1989) up to 2.9 milion. (year 1990), (Tab. 4). It should be mentioned that in all ichthyological samples it was found the presence of species that live permanently in small waters (coastal areas, bays) where the water heats up faster, rich in feed organisms and has a low flow. In these areas, the following species predominate: - bleak, gudgeon, bitterling, round goby, stone moroko, whose share is $-81.4 \%$. 
Tab. 4 The diversity and abundance of juvenile fish during the passive migration in the lower course of the Prut river (the segment of the village Brânza - the village Câșlița), (thousands of individuals

\begin{tabular}{|c|c|c|c|c|c|c|c|c|}
\hline \multirow{2}{*}{ Fish species } & \multicolumn{8}{|c|}{ Years } \\
\hline & 1989 & 1990 & 1991 & 2000 & 2002 & 2005 & 2009 & 2012 \\
\hline \multicolumn{9}{|c|}{ Fam. Clupeidae } \\
\hline Mackerel of Danube & - & 24,0 & - & - & - & - & - & - \\
\hline Black sea shad & - & - & - & 155,6 & 45,1 & 158,6 & 106,0 & 14,7 \\
\hline \multicolumn{9}{|c|}{ Fam. Cyprinidae } \\
\hline Roach & 1272,6 & 288,3 & 2716,0 & 757,6 & 45,7 & 1110,2 & 1082,0 & 175,1 \\
\hline Chub & 205,2 & - & - & 9829,1 & 248,0 & 1823,8 & 1035,5 & 24,0 \\
\hline Asp & 246,0 & - & - & 20165,6 & 78,9 & 634,4 & 752,0 & 35,0 \\
\hline Bleak & 1252,1 & 841,0 & 7663,7 & 1509,2 & 1590,5 & 2379,0 & 2933,0 & 220,2 \\
\hline White bream & 184,7 & - & 2182,7 & 323,4 & 320,1 & 555,1 & 526,0 & 51,3 \\
\hline Freshwater bream & 492,6 & 48,8 & 3880,5 & 982,9 & 2797,6 & 475,8 & 403,0 & 77,6 \\
\hline White-eye-bream & - & - & - & 196,6 & 327,1 & 396,4 & 342,0 & 61,7 \\
\hline Vimba bream & 143,7 & - & - & 196,6 & - & 79,3 & 323,5 & 28,9 \\
\hline Carp & 718,4 & - & 1067,1 & 1249,2 & 1545,4 & 1030,8 & 653,0 & 54,5 \\
\hline Silver Crucian Carp & 533,7 & 96,1 & 2619,2 & 3360,9 & 879,8 & 951,6 & 858,5 & 88,4 \\
\hline Barbel & 164,2 & - & - & - & 248,1 & 79,3 & 61,5 & - \\
\hline Common nase & - & - & - & 2029,2 & 45,5 & 237,9 & 221,5 & - \\
\hline Stone moroko & - & 48,1 & 242,5 & 196,6 & 248,1 & 79,3 & 53,5 & 8,2 \\
\hline Gudgeon & 985,3 & 192,2 & 970,0 & 1572,0 & 169,2 & 1506,7 & 1288 & 144 \\
\hline Ide & - & - & - & 66,2 & - & - & - & - \\
\hline Tench & - & - & - & 63,8 & - & - & - & - \\
\hline Rudd & 821,0 & - & 145,5 & - & 124,0 & - & 76,0 & 5,7 \\
\hline Belica & 410,5 & - & 194,0 & - & - & - & - & - \\
\hline Bitterling & 20,5 & 1129,3 & 970,0 & - & - & - & - & - \\
\hline \multicolumn{9}{|c|}{ Fam. Percidae } \\
\hline Pike-perch & 102,6 & - & 533,3 & 11287,7 & 710,6 & 1665,3 & 1327,5 & 97,7 \\
\hline European perch & - & - & 97,0 & 589,7 & 124,2 & 634,4 & 522,0 & 82,6 \\
\hline Ruffe & 82,1 & - & - & - & - & 1903,2 & 1366,5 & 175,8 \\
\hline \multicolumn{9}{|c|}{ Fam. Siluridae } \\
\hline Catfish & 41,0 & - & 145,5 & 1179,5 & 169,2 & 475,8 & 426,0 & 49,6 \\
\hline \multicolumn{9}{|c|}{ Fam. Odontobutidae } \\
\hline Round goby & 780,0 & 216,2 & 485,0 & 5834,1 & 1083,0 & 3568,5 & 2515,5 & 329,7 \\
\hline \multicolumn{9}{|c|}{ Fam. Cobitidae } \\
\hline Burbot & 287,4 & 72,1 & 242,5 & 60,2 & 925,0 & 555,1 & 490,0 & 51,2 \\
\hline \multicolumn{9}{|c|}{ Fam. Centrarchidae } \\
\hline Danube streber & - & - & - & 63,1 & - & - & - & - \\
\hline Sun Perch & - & - & 48,5 & - & - & - & - & - \\
\hline Total & 8743,2 & 2956,1 & 23330,7 & 61668,8 & 11725,1 & 20299,6 & 17362,5 & 1775,9 \\
\hline
\end{tabular}

Note : years 1989, 1990, 1991 - Scientific Research Station in the field of Fisheries, years: 2000, 2002 - Service of Fisheries, years: 2005, 2009, 2012 - Institute of Zoology 
The onset of mass brood migration usually occurs in the second decade of May. The migration of juvenile fish, with some decreases, in significant quantities continues until the third decade of July, which is probably related to the gradual exit of juvenile fish, as they grow, from Manta and Beleu lakes.

In 1990, the Manta puddles were supplied with water at the minimum level and their area decreased by 420 ha. In 1991, after long rains, the water level in the Danube River and in the Costești-Stânca accumulation lake and starting with April 30, the water level in the Prut River rose suddenly. Lake Beleu, which dried up completely in 1990, at the end of May was filled with water and the migration of fish to the breeding sites was found. But the unstable hydrological regime and the low water level in the Manta puddles and Beleu lake require the fattening of the migratory juvenile fish only in the Danube River [11, 13].

Therefore, it can be concluded that the lower course of the Prut River is generally used for breeding, and its fishery resources are directly dependent on the water flows during the breeding period and the state of the fishery resources on the lower course of the Danube River.

Research conducted in 2014 on the Chircani - Cahul segment showed that among the economically valuable species, resulting from the migration of juvenile fish, predominated the populations of freshwater bream (73.3 thousand ex.) and pike-perch (68.1 thousand ex.) followed by the populations of carp (20.9 thousand ex.) and catfish (10.5 thousand ex.) (Tab. 5). Among the species with lower economic value, the populations of roach (120.4 thousand ex.) and silver crucian carp (78.5 thousand ex.) had the highest productivity, followed by those of white bream (60.3 thousand ex.) and perch (26.2 thousand ex.). The highest productivity had the economically inalienable species: bleak (268.6 thousand ex.), round-goby (387.0 thousand ex.), ruffe (206.8 thousand ex.) and gudgeon (163.8 thousand ex.).

Tab. 5 Abundance of sapling in the Prut River on the section between Chircani village - Câșlița village during the migration period of 2014 (thousands of individuals)

\begin{tabular}{|c|c|c|c|c|}
\hline \multirow{2}{*}{ Fish species } & \multicolumn{2}{|c|}{ segment } & \multicolumn{2}{c|}{ segment } \\
& \multicolumn{2}{|c|}{ S. Chircani - or. Cahul } & \multicolumn{2}{c|}{ s. Brînza - s. Câșlița } \\
\cline { 2 - 5 } & Abundance & $\begin{array}{c}\text { Percentage } \\
\text { ratio\% }\end{array}$ & Abundance & Percentage ratio\% \\
\hline Black sea shad & 17,3 & 1,1 & 16,6 & 0,9 \\
\hline Roach & 120,4 & 7,7 & 99,1 & 5,3 \\
\hline Chub & - & - & 16,5 & 0,9 \\
\hline Asp & - & - & 35,6 & 1,9 \\
\hline Freshwater bream & 73,3 & 4,7 & 71,6 & 3,9 \\
\hline White-eye-bream & - & - & 60,6 & 3,3 \\
\hline Silver crucian carp & 78,5 & 5,0 & 82,6 & 4,4 \\
\hline Vimba bream & - & - & 5,5 & 0,3 \\
\hline Rudd & 6,0 & 0,4 & 5,7 & 0,3 \\
\hline White bream & 60,3 & 3,8 & 57,8 & 3,1 \\
\hline
\end{tabular}




\begin{tabular}{|c|c|c|c|c|}
\hline Bleak & 258,6 & 16,7 & 247,5 & 13,5 \\
\hline Carp & 20,9 & 1,3 & 88,1 & 4,7 \\
\hline Gudgeon & 163,8 & 10,4 & 157,0 & 8,5 \\
\hline Stone maroko & 8,6 & 0,5 & 8,2 & 0,4 \\
\hline SCatfish & 10,5 & 0,7 & 49,6 & 2,7 \\
\hline Freshwater bream & 26,2 & 1,7 & 82,6 & 4,4 \\
\hline Pike-perch & 68,1 & 4,3 & 143,2 & 7,7 \\
\hline Ruffe & 206,8 & 13,2 & 198,2 & 10,7 \\
\hline Burbot & 60,3 & 3,8 & 57,8 & 3,1 \\
\hline Round goby & 387,8 & 24,7 & 371,7 & 20,0 \\
\hline Total & $\mathbf{1 5 6 7 , 4}$ & & $\mathbf{1 8 5 5 , 5}$ & \\
\hline
\end{tabular}

In the lower course of the Prut River small species with low economic value predominate $(55.5 \%)$ and are represented by silver crucian carp - $15.3 \%$ with 7 age groups in which 2 years old groups predominate $(24.5 \%)$, as well as 3 years $(27.5 \%)$ and 4 years $(29.5 \%)$.

Compared to the period 2010-2015, the silver crucian carp populations decreased by $19.4 \%$ when they had a share of $34.7 \%$. This is explained by the disturbance of natural reproduction (low water levels in recent years during the breeding period, so that the bushes in Manta and Lake Beleu puddles were not covered with water on their entire surface, the small number of carp breeders and freshwater bream, etc.).

The crucian carp is followed by european perch 15.3\% (during the years 2008-2014-5.0\%). The European Perch population is represented by 6 dominant age groups, the groups of 2 years (14.6\%), 3 years $(34.8 \%)$ and 4 years $(33.8 \%)$. White-eye-bream with flattened muzzle constitutes $11.2 \%$ (during the years 2008-2014-23.3\%) and is represented by 6 dominant age groups being the groups of 2 years (11.1\%), 3 years (34.8\%) and 4 years $(33.8 \%)$.

Large species constitute $36.3 \%$, being represented by freshwater bream 11.9\% (2.3 times higher than in the year 2008-2014) and by 6 dominant age groups being the 2-year groups $(33.3 \%), 3$ years $(22.7 \%)$ and 4 years $(16.7 \%)$. Carp follows- $8.5 \%$ represented by 7 dominant age groups being the groups of 2 years $(16 \%), 3$ years $(30.5 \%)$ and 5 years $(19.6 \%)$.

The pike-perch constitutes $6.8 \%$, but the population is found in small numbers. A slight increase was reported to catfish (3.0\%). Species without economic value constitute $8.2 \%$ [7].

\section{Conclusions}

The ichthyofauna of the lower course of the Prut River is mostly influenced by anthropogenic actions (drying of ponds - about 30 thousand ha only on the territory of the Republic of Moldova, construction of Costesti-Stânca dam, tributary regularization, sand excavation, pebbles and river stone). from the minor riverbed, pollution with untreated wastewater and domestic water, etc.) is in continuous quantitative and qualitative decline, especially of species with economic value (starlet, basratd strungeon, burbot, ide, eel).

Many species currently introduced in the Red Book (3rd ed.) Of the Republic of Moldova have become extinct or are on the verge of extinction. 
There are no, on both sides, systematic studies on the state of fishery resources, structural-functional changes of fish populations in current and future ecological conditions.

\section{Bibliography}

1. ANTIPA, Gr. Fauna ihtiologică a României. București, 1909. 289 p.

2. BĂNĂRESCU, P. Fauna Republicii Populare Române: Pisces - Osteichthyes. Ed. Academiei Republicii Populare Române, 1964. 959 p.

3. BULAT, DM. Ihtiofauna Republicii Moldova: ameninţări, tendinţe şi recomandări de reabilitare. Chișinău: Foxtrod, 2017. 343 p. ISBN 978-9975-89-070-0.

4. BULAT, DM., BULAT, DN., DAVIDEANU, A., IRINEL E., POPESCU, DAVIDEANU, GR. Studiu comun Romania - R. Moldova cu privire la ihtiofauna din lacul de acumulare Stânca-Costești. In: AACL Bioflux 9(3): 2016, pp. 550-563. ISSN 1844-8143.

5. BULAT, DM., BULAT, DN., TODERAŞ, I., USATIII, M., ZUBCOV, E., UNGUREANU, L. Biodiversitatea, Bioinvazia şi Bioidicaţia (în studiul faunei piscicole din Republica Moldova). Chișinău: Foxtrod, 2014,430 p.

6. DAVIDEANU Gr. ș.a. Ihtiofauna râului Prut. Societatea ecologică pentru Protecția și Studierea Florei şi Faunei Sălbatice "Aquaterra", Societatea Bioremedierii Ecosistemelor Acvatice şi Umede "Euribiont”. Iași, 2008, 80 p.

7. Inspectoratul de Stat pentru protecția și reproducerea resurselor piscicole și reglementarea pescuitului. Rapoarte anuale, aa. 1952, 1955, 1982, 1983, 1985, 1987, 1992, 1993, 1996, 1998, 2001, 2002, 2005.

8. Institutul de Cercetare-Dezvoltare pentru Ecologie Acvacultică, Pescuit și Acvacultură Galați, Raport Tehnico-Științific privind situația stocurilor de resurse acvatice vii (pești) din râul Prut şi lacul de acumulare Stânca-Costeşti în perioada 2006-2007.

9. Institutul de Zoologie, Evaluarea stării resurselor piscicole. Chişinău: "Balacron", 2017, -142 p. ISBN 978-9975-128-92-6. [574.5/.5+639.2](478) E-93.

10. Năvodaru I. ș. a. Estimarea stocurilor de peşti şi pescăriilor. Metode de evaluare şi prognoză a resurselor pescăreşti. Ed. Dobrogea, 2008, p. 46-61.

11. Stațiunea de Cercetări Științifice în Domeniul Pisciculturii. Rapoarte, 1988, 1998, 2004.

12. USATÎI Adrian, USATII Marin, TODERAȘ Ion, ȘAPTEFRAȚI Nicolae. ATLAS: "Peștii apelor Moldovei". Academia de Științe a Moldovei, Institutul de Zoologie. - Chişinău: S. n., 2015 (F.E.-P. “Tipografia Centrală”). - 192 p. ISBN 978-9975-53-578-6. CZU 597.2/.5(478) (03) P 53.

13. USATÎI, AD., USATÎI, M., ŞAPTEFRAȚI, N., DADU, A. Resursele piscicole naturale ale Republicii Moldova, ed. Balacron, Chişinău, 2016, 124 p.

14. USATÎI, M. Evoluţia, conservarea şi valorificarea durabilă a diversităţii ihtiofaunei ecosistemelor acvatice ale Republicii Moldova. Autoreferat al tezei de doctor habilitat în ştiinţe biologice, Chişinău, 2004, 48 p.

15. USATÎI, M., ŞAPTEFRAȚI, N., BULAT DM. ş.a. Starea ihtiocenozelor din ecosistemele acvatice naturale şi măsuri de amelioarare. Tipograf. "Balacron”. Chişinău, 2018, 48 p. ISBN 978 -9975- 3255-6-1.

16. ГРИМАЛЬСКИИ, В.Л. Очерк рыбного хозяйства р. Прут. Кишиневский Сельхохозяйственный Институт им. М.В. Фрунзе. Кишинев, 1958, 143 с.

17. Дементьева Т. Ф. Биологическое основание промысловых прогнозов. Изд. Пищевая 
промышленность. Москва, 1976.

18. ДОЛГИЙ, В.Н. Ихтиофауна Днестра и Прута (современное состояние, генезис, экология и биологические основы рыбохозяйственного использования). Изд. Штиинца. Кишинев, 1993, 323 c.

19. Коблицкая А.Ф. 1981. Определитель молоди пресноводных рыб. М.: Наука, с. 208.

20. Малкин Е.М., Александров А.К., Воронин В.М., Полторацкий С.В. 1981. Методические рекомендации по контролю за состоянием рыбных запасов и оценке численности рыб. М. : ВНИРО. с. 15.

21. Никольский Г.В. Теория динамики стада рыб как биологическая основа эксплуатации и воспроизводства рыбных ресурсов. Изд. Пищевая промышленность. Москва, 1974, 447 c.

22. ПОПА, ЈI.ЈI. Рыбы Молдавии. Справочник - определитель. Изд. Картя Молдовеняскэ. Кишинев, 1977, 200 с.

23. ПОПА, Л.Л. Рыбы бассейна р. Прут. Изд. Штиинца. Кишинев, 1976, 85 с. 